\title{
Leukaemic hypopyon in acute lymphoblastic leukaemia after interruption of treatment
}

\author{
G. MASERA, V. CARNELLI, C. UDERZO, C. TOSELLI, F. LASAGNI, \\ AND E. LAMBERTENGHI \\ Departments of Paediatrics and Clinical Ophthalmology, University of Milan School of Medicine, Italy
}

SUMMARY A 7-year-old girl was successfully treated for acute lymphoblastic leukaemia, and remained in remission after treatment had been completed in 3 years. Four months after cessation of treatment, iridocyclitis with hypopyon developed in one eye. Exudate from the anterior chamber contained numerous lymphoblasts. Local radiotherapy led to complete resolution of the ocular lesions, and the patient remains well 22 months later.

Leukaemic involvement of the retina, optic nerve or, occasionally, of the anterior chamber of the eye, was recorded by Ridgway et al. (1976) in $9 \%$ of acute lymphoblastic leukaemia (ALL) cases in children, and is often demonstrable at necropsy (Sansone and Mariotti, 1953; Allen and Straatsma, 1961; Evans, 1964; Kearney, 1973; Mark et al., 1974; Ridgway et al., 1976; Murray et al., 1977). We describe hypopyon as an isolated occurrence in a case of ALL 4 months after treatment had been stopped.

\section{Case report}

A 7-year-old girl with ALL was treated with vincristine $2 \mathrm{mg} / \mathrm{m}^{2}$ weekly for 5 weeks, together with prednisone $50 \mathrm{mg} / \mathrm{m}^{2}$ daily for one month, and full remission was obtained. CNS prophylaxis was then given with 2400 rads of ${ }^{60} \mathrm{CO}$ cranial irradiation in 24 days, and intrathecal methotrexate $6 \mathrm{mg} / \mathrm{m}^{2}$ weekly for 6 weeks, repeated every 3 months for the next 18 months. Remission was maintained on 6mercaptopurine (6-MP) $50 \mathrm{mg} / \mathrm{m}^{2}$ daily and methotrexate $20 \mathrm{mg} / \mathrm{m}^{2}$ weekly. Reinduction therapy was given every 3 months: vincristine $1.5 \mathrm{mg} / \mathrm{m}^{2}$ weekly for 3 weeks; prednisone $30 \mathrm{mg} / \mathrm{m}^{2}$ daily for 3 weeks. After 3 years of complete remission, treatment was stopped in April 1976.

Four months later, while still in complete haematological remission, our patient complained of severe photophobia. The left eye showed perikeratic injection, infiltration and congestion of the iris, and copious whitish hypopyon which occupied almost half of the anterior chamber; there was absence of synechiae, little aqueous flare, and the pupil was round central and reacting. The right eye was normal.
The haematological findings remained normal, as did the bone marrow biopsy and the cerebrospinal fluid (CSF). A diagnosis of iridocyclitis was made, and local treatment with atropine and cortisone, with antibiotics and dexamethasone systematically, was begun.

Within 3 weeks there was complete regression of the ocular lesions and treatment was stopped. Two months later the ocular condition recurred in the left eye. The same treatment was repeated, but after 10 days there had been no improvement, and a subconjunctival injection of betamethasone was given. During the next 10 days there was progressive absorption of the hypopyon with some residual swelling of the iris. The eye returned to normal after a further month of local treatment (atropine and cortisone).

Two months later there was a second relapse with similar appearances of the left eye, this time with haemorrhagic striae mixed with the hypopyon. Treatment (atropine, cortisone locally, and subconjunctival injection of betamethasone) resulted only in some relief of symptoms, but shortly afterwards there was copious hypopyon. Fluid was then withdrawn from the anterior chamber of the left eye and this showed a cell population composed mainly of lymphoblasts. Bone marrow and CSF remained normal. A diagnosis of leukaemic hypopyon was made. Radiotherapy (total of 390 rads in a 22-day period) to the anterior segment of the eye was given and resulted in complete remission. Further systemic treatment (vincristine and prednisone, followed by 6-MP and methotrexate) was then given.

After 22 months, the clinical and haematological findings remain normal.

\section{Discussion}

Ridgway et al. (1976) suggested that the eye, because of its anatomical structure, can behave as a 'pharmacological sanctuary' in leukaemia. The anterior segment is the most rarely affected site within the eye, but a few other cases have been reported (Kearney, 1973; Mark et al., 1974; Murray et al., 1977). In all these reported cases however, this complication occurred during haematological relapse 
or in association with meningeal leukaemia. In our case the patient was off treatment and there were no other leukaemic manifestations.

Although radiotherapy to the eye proved effective, a case such as this must be regarded as having relapsed and therefore requiring further courses of antileukaemic drugs.

We thank Professor F. Fossati who performed ocular radiotherapy.

\section{References}

Allen, R. A., and Straatsma, B. R. (1961). Ocular involvement in leukemia and allied disorders. Archives of Ophthalmology, 66, 490-508.

Evans, A. E. (1964). Central nervous system involvement in children with acute leukemia; a study of 912 patients. Cancer, 17, 256-258.

Kearney, W. F. (1973). Leukemic hypopyon: a report of two cases. American Journal of Ophthalmology, 59, 495-497.

Mark, L. E., Rouhani, J., and Sawitsky, A. (1974). Leukemic iris infiltration in a case of meningeal leukemia. Annals of Ophthalmology, 6, 669-674.

Murray, K. H., Paolino, F., Goldman, J. M., Galton, D. A. G., and Grindle, C. F. J. (1977). Ocular involvement in leukaemia. Report of three cases. Lancet, 1, 829-831.

Ridgway, E. W., Jaffe, N., and Walton, D. S. (1976). Leukemic ophthalmology in children. Cancer, 38, 1744-1749.

Sansone, G., and Mariotti, L. (1953). Le manifestazioni oculari delle leucemie acute dell'infanzia con particolare riguardo alla retinopatia leucemica. Annali di of ttalmologia e clinica oculistica, 3, 169-194.

Correspondence to Professor G. Masera, Department of Paediatrics, University of Milan, Clinica De Marchi, Via Commenda, 9-20122 Milan, Italy.

\title{
Reye's syndrome associated with respiratory syncytial virus infection
}

\author{
N. GRIFFIN, J. W. KEELING, AND A. H. TOMLINSON \\ Department of Paediatrics and Pathology, John Radcliffe Hospital, and the Virology Laboratory, \\ Churchill Hospital, Headington, Oxford
}

SUMMARY An upper respiratory tract infection in a 22-month-old boy was followed by rapid loss of consciousness, hypoglycaemia, uraemia, and death. Necropsy examination showed fatty change of liver and kidneys, severe cerebral oedema, bronchiolitis, and endocardial fibroelastosis affecting the left ventricle. Immunofluorescence staining showed infection with respiratory syncytial virus (RSV). The clinical and pathological findings were those of Reye's syndrome, not previously reported accompanying RSV infection.

Reye et al. (1963) described a syndrome of acute encephalopathy and fatty degeneration of the viscera. The association with an acute respiratory virus infection has often been noted, but respiratory syncytial virus (RSV) has not, to our knowledge, been implicated. We report a fatal case of Reye's syndrome associated with a RSV infection.

\section{Case report}

A boy of 22 months developed a mild upper respiratory tract infection with nonproductive cough and coryza which was treated with a proprietory linctus. On the 3rd morning he did not wake at the usual time but was seen by his mother at 8.30 a.m. to be sleeping peacefully with normal respirations. At
9.30 a.m. she found him blue, limp, and dyspnoeic.

On admission one hour later he was found to have peripheral vasoconstriction, central cyanosis, and to be in shock. Systolic blood pressure was $60 \mathrm{mmHg}$, pulse $88 / \mathrm{min}$, and respiratory rate $48 / \mathrm{min}$. He responded only to painful stimuli, his respirations were shallow, noisy, and irregular. There was diminished air entry, particularly on the left, coarse moist sounds and expiratory rhonchi were present bilaterally. The liver was not palpable. Retinal examination and reflexes were normal. His condition deteriorated rapidly; coma deepened, muscle tone increased, plantar responses became extensor. Treatment with dextrose/saline, hydrocortisone, antibiotics, and oxygen was ineffective; he died 3 hours after admission.

Investigations. Total WBC count $18800 / \mathrm{mm}^{3}(18 \cdot 8$ $\left.\times 10^{9} / \mathrm{l}\right)$ with mild neutrophilia, blood urea 69 $\mathrm{mg} / 100 \mathrm{ml}(11.5 \mathrm{mmol} / \mathrm{l})$, bicarbonate $17 \mathrm{mEq} / \mathrm{l}$, blood sugar $10 \mathrm{mg} / 100 \mathrm{ml}(0.56 \mathrm{mmol} / \mathrm{l}), \mathrm{CSF}$ and blood cultures were sterile. Nose and throat swabs yielded normal flora.

Necropsy. A well nourished baby boy $89 \mathrm{~cm}$ crown/ heel length, weighing $11.6 \mathrm{~kg}$. The brain was swollen $(1170 \mathrm{~g})$; slicing after fixation showed obliteration of sulci. The larynx was injected, trachea and main bronchi contained purulent mucus, 